\title{
Sensitivity of air pollution simulations with LOTOS-EUROS to the temporal distribution of anthropogenic emissions
}

\author{
A. Mues ${ }^{1,{ }^{*}}$, J. Kuenen ${ }^{2}$, C. Hendriks ${ }^{2}$, A. Manders ${ }^{2}$, A. Segers ${ }^{2}$, Y. Scholz ${ }^{3}$, C. Hueglin ${ }^{4}$, P. Builtjes ${ }^{1,2}$, and M. Schaap ${ }^{2}$ \\ ${ }^{1}$ Freie Universität Berlin, Carl-Heinrich-Becker-Weg 6-10, 12165 Berlin, Germany \\ ${ }^{2}$ TNO, Dept. of Climate, Air and Sustainability, P.O. Box 80015, 3508 TA Utrecht, the Netherlands \\ ${ }^{3}$ Deutsches Zentrum für Luft- und Raumfahrt (DLR), Institut für Technische Thermodynamik Systemanalyse und \\ Technikbewertung Pfaffenwaldring 38-40, 70569 Stuttgart, Germany \\ ${ }^{4}$ EMPA, Swiss Federal Laboratories for Materials Science and Technology, Überlandstraße 129, 8600 Dübendorf, Switzerland \\ *now at: IASS Potsdam, Institute for Advanced Sustainability Studies e.V., Berliner Strasse 130, 14467 Potsdam, Germany
}

Correspondence to: A. Mues (andrea.mues@iass-potsdam.de)

Received: 29 April 2013 - Published in Atmos. Chem. Phys. Discuss.: 23 July 2013

Revised: 5 December 2013 - Accepted: 6 December 2013 - Published: 27 January 2014

\begin{abstract}
In this study the sensitivity of the model performance of the chemistry transport model (CTM) LOTOSEUROS to the description of the temporal variability of emissions was investigated. Currently the temporal release of anthropogenic emissions is described by European average diurnal, weekly and seasonal time profiles per sector. These default time profiles largely neglect the variation of emission strength with activity patterns, region, species, emission process and meteorology. The three sources dealt with in this study are combustion in energy and transformation industries (SNAP1), nonindustrial combustion (SNAP2) and road transport (SNAP7). First of all, the impact of neglecting the temporal emission profiles for these SNAP categories on simulated concentrations was explored. In a second step, we constructed more detailed emission time profiles for the three categories and quantified their impact on the model performance both separately as well as combined. The performance in comparison to observations for Germany was quantified for the pollutants $\mathrm{NO}_{2}, \mathrm{SO}_{2}$ and $\mathrm{PM}_{10}$ and compared to a simulation using the default LOTOS-EUROS emission time profiles. The LOTOS-EUROS simulations were performed for the year 2006 with a temporal resolution of $1 \mathrm{~h}$ and a horizontal resolution of approximately $25 \times 25 \mathrm{~km}^{2}$.

In general the largest impact on the model performance was found when neglecting the default time profiles for the three categories. The daily average correlation coefficient for instance decreased by $0.04\left(\mathrm{NO}_{2}\right), 0.11\left(\mathrm{SO}_{2}\right)$ and 0.01 $\left(\mathrm{PM}_{10}\right)$ at German urban background stations compared to
\end{abstract}

the default simulation. A systematic increase in the correlation coefficient is found when using the new time profiles. The size of the increase depends on the source category, component and station. Using national profiles for road transport showed important improvements in the explained variability over the weekdays as well as the diurnal cycle for $\mathrm{NO}_{2}$. The largest impact of the SNAP1 and 2 profiles were found for $\mathrm{SO}_{2}$. When using all new time profiles simultaneously in one simulation, the daily average correlation coefficient increased by $0.05\left(\mathrm{NO}_{2}\right), 0.07\left(\mathrm{SO}_{2}\right)$ and $0.03\left(\mathrm{PM}_{10}\right)$ at urban background stations in Germany. This exercise showed that to improve the performance of a CTM, a better representation of the distribution of anthropogenic emission in time is recommendable. This can be done by developing a dynamical emission model that takes into account regional specific factors and meteorology.

\section{Introduction}

Air pollution levels are controlled by meteorological conditions, atmospheric processes and emission regime. Chemistry transport models (CTM) have been developed to assess the fate of air pollutants. Large efforts have been devoted to improving the process descriptions and meteorological input data. Nevertheless, models still underestimate the variability of air pollutant levels in general and as function of meteorology compared to observations (Li et al., 2013; Stern et al., 
2008). It has been posed by several authors that the emission data used in CTMs are too static (Mues et al., 2012; Menut et al., 2012; Skjøth et al., 2011). Since the early 1990s, the handling of anthropogenic emissions in CTMs has remained the same. In principle, annual average emission totals are distributed across the domain and combined with average time profiles per sector to arrive at an emission at every point in time. In reality, emission strengths vary with activity patterns, region, species, emission process and meteorology. These variations are currently largely neglected but may be important as atmospheric conditions during release and transport impact the fate of the emitted air pollutants. As an example, accounting for the change in temporal emission characteristics of the energy sector when considering the variability of the contribution of renewable energy with meteorology significantly changes the impact of the power sector in the case of energy transition, as illustrated by Hendriks et al. (2013). This was explained by the occurrence of the highest emissions from fossil fuel power plants during atmospheric conditions that favor build-up of pollutants (e.g., during the night, low wind speeds). Hence, accounting for temporal variability may be important for mitigation strategies as efficiency of measures may be affected. As such, correlations between meteorology and emission strength may impact climate studies for short-lived climate forcers. Finally, air quality forecasting (Kukkonen et al., 2012) could be improved with a more detailed description of the temporal distribution of the emission input. Inverse-modeling studies are hampered by a lack of temporal variation in a priori emission data (Peylin et al., 2011).

The sensitivity of CTMs to changes in the temporal distribution of emissions is tested in a few studies by comparing simulation results using default time profiles and constant emissions over time. De Meij et al. (2006) found that the daily and weekly temporal distributions of emissions are only important for $\mathrm{NO}_{\mathrm{x}}, \mathrm{NH}_{3}$ and aerosol nitrate, whereas for all aerosol species $\left(\mathrm{SO}_{4}, \mathrm{NH}_{4}\right.$, particulate organic matter and black carbon) the seasonal temporal variations used in the emission inventory are important. Regional daytime ozone concentrations were found not to be sensitive to changes in the temporal allocation of emissions, while nighttime ozone concentrations are lower under uniform profiles than under time-varying profiles (Tao et al., 2004). Similar results were found when changing the daily cycle of mobile source emission in the Community Multi-scale Air Quality (CMAQ) Model, which entails substantial changes in simulated ozone concentrations, especially in urban areas at night (Castellanos et al., 2009). Wang et al. (2010) found an increase in correlation when considering different emission factors for the day of week and in the diurnal cycle compared to a simulation with constant emissions. However, the impact of neglecting the emission time profiles also depends on the quality of the default time profiles. Observations show that ozone concentrations are higher on the weekend than during weekdays; this signal has been successfully captured by the
CMAQ model (Pierce et al., 2010). Pierce et al. (2010) also recommended improving the estimate of mobile source $\mathrm{NO}_{\mathrm{x}}$ emissions and their temporal distributions, with special emphasis on diesel cars to better explain observed trends in the extent of the weekend-weekday effect in ozone.

In the literature, less attention has been given to the development of emission time profiles and their impact on the model performance. Emission time profiles for SNAP (Selected Nomenclature for Air Pollutants) category 2 (nonindustrial combustion), which are based on the actual daily average temperature per grid cell, are used in the EMEP (Simpson et al., 2012) and CHIMERE (Bessagnet et al., 2012) models, but the impact on the model performance is not documented. Menut et al. (2012) used hourly $\mathrm{NO}_{2}$ measurements at European stations close to roadside areas as a proxy for road traffic sources in order to construct new time profiles, which were then tested in the CHIMERE model. The most important impact concerns $\mathrm{NO}_{2}$ concentrations, which are $10-20 \%$ higher. The daily ozone peak remains relatively insensitive to this improvement, whereas concentrations of pollutants during nighttime are closer to the measurements with the new profiles. The simulation results show very different diurnal variation of emissions from country to country and suggest the use of a new hourly emission factor data set for various countries. Skjøth et al. (2011) found an improvement in CTM modeling by applying a dynamic ammonium emission model that accounts for local agriculture management and local climate.

In this study we test the sensitivity of the model performance for improved temporal emission information. For this purpose we focus on improving the emission variability for a select number of components and sectors for Germany. As such we explore whether it is worthwhile to make the effort to improve the emission description to an explicit temporal emission model. The three source categories dealt with in this study are combustion in energy and transformation industries (SNAP1), nonindustrial combustion (SNAP2) and road transport (SNAP7). First of all, we explored the impact of neglecting the temporal emission profiles for these SNAP categories on simulated pollutant concentrations with the LOTOS-EUROS chemistry transport model (Schaap et al., 2008). In a second step we constructed more detailed emission time profiles for the three categories and tested them in model simulations using each new profile separately as well as all three profiles simultaneously in one simulation. We compared the results for the pollutants $\mathrm{NO}_{2}, \mathrm{SO}_{2}$ and $\mathrm{PM}_{10}$ to measurements and to a model simulation using the default LOTOS-EUROS emission time profiles. 


\section{Method and data}

\subsection{The LOTOS-EUROS model}

The model employed in this study is the 3-D regional chemistry transport model LOTOS-EUROS version 1.8 , which is aimed at the simulation of air pollution in the lower troposphere. The model is of intermediate complexity in the sense that the relevant processes are parameterized in such a way that the computational demands are modest, enabling hour-by-hour calculations over extended periods of several years within acceptable CPU time. The domain used is bound at $35^{\circ}$ and $70^{\circ} \mathrm{N}$ and $15^{\circ} \mathrm{W}$ and $35^{\circ} \mathrm{E}$. The model projection is normal longitude-latitude and we used the standard grid resolution of $0.50^{\circ}$ longitude $\times 0.25^{\circ}$ latitude, approximately $25 \times 25 \mathrm{~km}^{2}$. In the vertical, the model extends to $3.5 \mathrm{~km}$ a.s.l. and uses the dynamic mixing layer approach to determine the model vertical structure (Kranenburg et al., 2013). The model is driven by short-range meteorological forecasts $(0-12 \mathrm{~h})$ from the ECMWF Operational Data stream (Table 2). Forecast data are used to ensure physical consistency in the data, which might be lost to a slight extent during analysis, and because these data are available from the operational air quality forecasts in which the model is also used. For the experiments in this study, the meteorological data are retrieved at a horizontal resolution of $0.50^{\circ}$ longitude $\times 0.25^{\circ}$ latitude and interpolated to the model grid if necessary; temporal resolution is three-hourly, with linear interpolation applied to obtain an hourly resolution. The boundary conditions are obtained from the MACC near-realtime forecasts as produced by the IFS/MOZART coupled system (Flemming et al., 2009). These enclose the LOTOSEUROS domain at the lateral as well as the upper boundary. The advection in all directions is handled with a monotonic advection scheme (Walcek et al., 1998). Gas-phase chemistry is described using the TNO CBM-IV scheme, which is a condensed version of the original scheme (Whitten et al., 1980). Hydrolysis of $\mathrm{N}_{2} \mathrm{O}_{5}$ is described explicitly (Schaap et al., 2004a). Cloud chemistry is described following Banzhaf et al. (2012). Aerosol chemistry is represented using ISORROPIA2 (Fountoukis and Nenes, 2007). Dry deposition is based on the well-known resistance approach, with the DEPAC parameterization for gases (Wichink Kruit et al., 2012) and the Zhang et al. (2001) parameterization for particles. Below-cloud scavenging is described using simple scavenging coefficients for gases (Schaap et al., 2004a) and particles (Simpson et al., 2003). Total $\mathrm{PM}_{10}$ in the LOTOS-EUROS model is composed of chemically unspecified primarily PM in the fine (PPM2.5) and coarse mode (PPMCO), black carbon $(\mathrm{BC})$, dust, ammonium $\left(\mathrm{NH}_{4}^{+}\right)$, sulfate $\left(\mathrm{SO}_{4}^{2-}\right)$, nitrate $\left(\mathrm{NO}_{3}^{-}\right)$and sea salt (Na in the fine and coarse mode). The LOTOS-EUROS model has participated in several international model intercomparison studies addressing ozone (Hass et al., 1997; Van Loon et al., 2007; Solazzo et al., 2012a) and particulate matter (Cuvelier et al., 2007; Hass et al., 2003;
Stern et al., 2008; Solazzo et al., 2012b) and shows comparable performance to other European models. For a detailed description of model version 1.8, we refer the reader to Hendriks et al. (2013), Wichink Kruit et al. (2012) and Schaap et al. (2009).

\subsection{The emission database}

The anthropogenic emissions used in this study are taken from the TNO-MACC emission database for 2005 (Kuenen et al., 2011; Denier van der Gon et al., 2010). This inventory is a Europe-wide, high-resolution $\left(0.125^{\circ} \times 0.0625^{\circ}\right.$ long.-lat.) inventory for $\mathrm{NO}_{\mathrm{x}}, \mathrm{SO}_{2}, \mathrm{NMVOC}, \mathrm{CH}_{4}, \mathrm{NH}_{3}$, $\mathrm{CO}, \mathrm{PPM}_{10}$ and $\mathrm{PPM}_{2.5}$. It is set up using official emissions reported by countries themselves. Emissions have been split into point and area sources and are given in aggregated sources categories (SNAP levels) as a total annual sum. SNAP level 1 is the highest aggregation level, distinguishing 10 different source sectors. National emission totals have been disaggregated spatially using actual point source locations and strengths as well as several proxy maps (e.g., population density, traffic intensity) (Kuenen et al., 2011). Elemental carbon emissions are separated from the chemically unspecified primary $\mathrm{PM}_{2.5}$ emissions following Schaap et al. (2004b), and primary organic carbon is included as a part of primary $\mathrm{PM}_{2.5}$. Natural emissions are calculated online using the actual meteorological data. Biogenic NMVOC and mineral dust emissions are prescribed following Schaap et al. (2009). Sea salt emissions are calculated following Mårtensson et al. (2003) and Monahan et al. (1986) from wind speed at $10 \mathrm{~m}$. The MACC global fire assimilation system (Kaiser et al., 2009) is used on an hourly basis.

The three source categories dealt with in this study are combustion in energy and transformation industries (SNAP1), nonindustrial combustion (SNAP2) and road transport (SNAP7). Nonindustrial combustion consists mainly of domestic combustion and is dominated by emissions from heating, though it also includes secondary contributions from processes such as cooking and heating of water. Road transport within TNO-MACC is subdivided into five categories (road transport exhaust emissions - 71: gasoline; 72: diesel; 73: other fuels and non-exhaust emission; 74: evaporation of gasoline; 75 : road, brake and tyre wear). The three sectors under investigation contribute a significant fraction of the emissions of several pollutants in Europe. As an example, the contribution of the different source sectors to German national emissions totals is given in Table 1. Road transport is the most important source for nitrogen oxides, carbon monoxide and particulate matter, with the highest contribution for nitrogen oxide reaching almost half the national total. The power sector is the largest source for sulfur dioxide and contributes significantly to nitrogen oxide emissions. Residential combustion contributes $10-20 \%$ of the total emissions of a few components. Given the strong seasonal signature, its importance in winter is significantly higher (see 
Table 1. Contribution of the different source sectors to German national emissions (\%). In addition to single sectors, the relative contribution for the three sectors studied here are also given. Finally, the last row provides the national emission total for all species (kt).

\begin{tabular}{llllllll}
\hline SNAP & $\mathrm{NO}_{\mathrm{x}}$ & $\mathrm{SO}_{2}$ & $\mathrm{NH}_{3}$ & $\mathrm{NMVOC}$ & $\mathrm{CO}$ & $\mathrm{PM}_{10}$ & $\mathrm{PM}_{2.5}$ \\
\hline 1 & 19.3 & 53.7 & 0.5 & 6.4 & 3.6 & 5.2 & 8.2 \\
2 & 6.4 & 12.9 & 0.5 & 3.3 & 20.5 & 11.1 & 18.6 \\
$3+4$ & 14.4 & 28.9 & 2.2 & 4.0 & 30.1 & 37.8 & 24.4 \\
5 & 0.7 & 3.8 & 0.0 & 6.8 & 0.1 & 0.0 & 0.0 \\
6 & 0.0 & 0.0 & 0.3 & 63.8 & 0.0 & 4.8 & 8.5 \\
7 & 48.5 & 0.1 & 1.7 & 13.3 & 41.5 & 18.4 & 25.5 \\
8 & 10.7 & 0.6 & 0.1 & 2.3 & 4.2 & 5.7 & 10.0 \\
9 & 0.0 & 0.0 & 0.0 & 0.0 & 0.0 & 0.0 & 0.0 \\
10 & 0.1 & 0.0 & 94.7 & 0.0 & 0.0 & 17.0 & 4.8 \\
$\mathbf{1}+\mathbf{2 + 7}(\mathbf{\%})$ & $\mathbf{7 4 . 2}$ & $\mathbf{6 6 . 7}$ & $\mathbf{2 . 7}$ & $\mathbf{2 3 . 0}$ & $\mathbf{6 5 . 6}$ & $\mathbf{3 4 . 7}$ & $\mathbf{5 2 . 3}$ \\
All (kt) & 1457 & 540 & 578 & 1163 & 3731 & 218 & 123 \\
\hline
\end{tabular}

below). Combined, the three source sectors explain 74, 67, 52 and $35 \%$ of the national reported emissions of $\mathrm{NO}_{\mathrm{x}}, \mathrm{SO}_{2}$, $\mathrm{PM}_{2.5}$ and $\mathrm{PM}_{10}$, illustrating the potential impact of adaptations to the temporal profiles.

Emissions are distributed in the vertical following the profiles defined for the EURODELTA project (Thunis et al., 2008). For example, for SNAP1, $8 \%$ of the total emissions are emitted in a height range between 170 and $310 \mathrm{~m}, 46 \%$ between 310 and $470 \mathrm{~m}, 29 \%$ between 470 and $710 \mathrm{~m}$, and $17 \%$ between $710 \mathrm{~m}$ and $990 \mathrm{~m}$. Since the height of the model layers depends on the mixing height the distribution of the emission to the model layers is recomputed every time step. Emission composition (e.g., VOC split) was kept constant throughout all simulations. The direct $\mathrm{NO}_{2}$ emission fraction for all combustion sources is set to $3 \%$. This relatively low direct $\mathrm{NO}_{2}$ percentage for traffic does not impact our analysis. A sensitivity simulation (not shown) carried out using updated direct $\mathrm{NO}_{2}$ percentage based on fleet composition, yielding $20 \%$ on average for diesel cars, showed that modeled $\mathrm{NO}_{2}$ is influenced by less than $0.5 \%$ in the regional background across Germany. Only in the grid cells including large cities are values between 0.5 and $1.5 \%$ found.

\subsection{Model simulations and measurements}

To test the sensitivity of the model to the temporal variability of emissions six model simulations were performed. First, a model simulation without emission profiles for SNAP 1, 2 and 7 (LE_const127) and thus using constant emissions for these sectors in time was compared to a base simulation (LE_Default), which uses the default emission time profiles for all SNAP categories. We constructed more detailed emission time profiles for the SNAP1, SNAP2 and SNAP7 categories, which are described in Sect. 3. Three simulations were carried out to quantify the impact of each new profile separately (LE_SNAP1, LE_SNAP2, LE_SNAP7), while keeping all other profiles as default. In a last step, all three new time profiles were used simultaneously in one simu- lation (LE_SNAP127). To include long-range transport, the runs were performed for the European domain. All model simulations have been performed using annual emission totals for the year 2005 and the meteorology of the year 2006. The meteorological year 2006 was chosen because it was a very variable year in terms of air quality, including clean and heavy polluted periods in Europe. Moreover, data to construct time profiles for SNAP1 (data from the REMix model) and SNAP7 (traffic count data) were available for this year. The model setup, the description and the name of the simulations are summarized in Table 2.

The current emission time profiles per sector are old and often based on information representative of one or several countries (e.g., Dutch traffic count data for SNAP 7). However, they are applied to all countries in the model domain. In this study we constructed emission time profiles representative for Germany and evaluated the impact by evaluation against German monitoring data. Air pollutant measurements at German stations with an hourly or daily time resolution from the AirBase database (AIRBASE, 2012) were selected and acquired. Only time series with a minimum of $60 \%$ data coverage for 2006 for an individual component and time resolution were chosen for the evaluation. Model data are neglected if no measurements are available on a specific hour or day in the time series. Note that for the hourly and daily time series of the individual components the location and the number of the stations included in the measured and modeled annual averages are variable. For the horizontal grid resolution of about $25 \times 25 \mathrm{~km}^{2}$ mainly rural background stations are representative. However, because the focus of this study is also on SNAP7 and SNAP2, which are dominant in urban regions, urban background stations are also included in the statistics. This is despite the fact that the absolute concentration is highly underestimated at these stations. For the interpretation of the results, the main interest is on the ability of the model to reproduce the temporal variability of the measured pollutant concentrations. Therefore, mainly the results for the correlation coefficient are discussed in the Sect. 4. 
Table 2. Description of the model simulations.

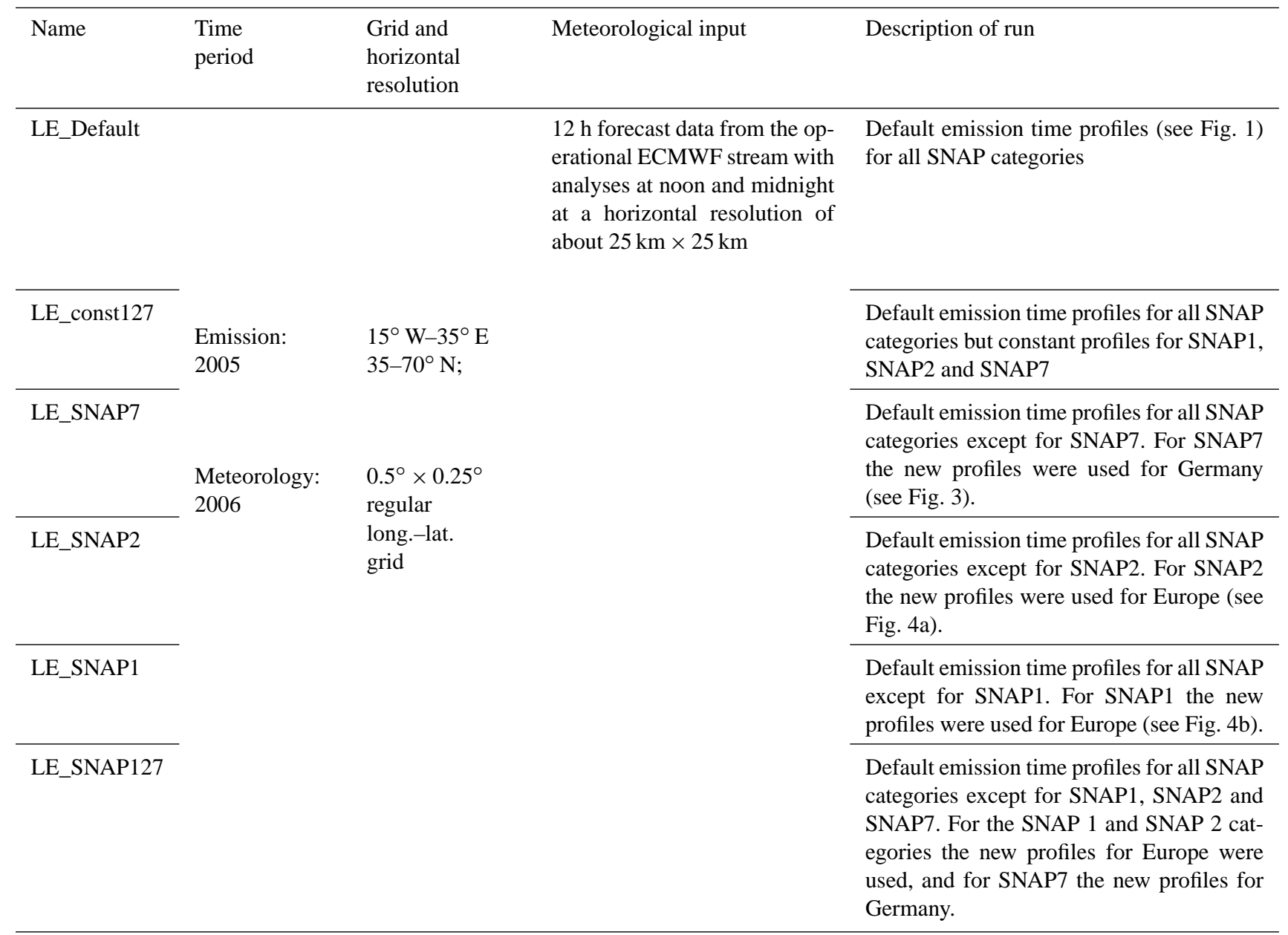

\section{Improved emission time profiles}

The default emission time factors currently used in the LOTOS-EUROS model (Builtjes et al., 2003) are given for the hour of the day, the day of the week and the month of the year. The default profiles for SNAP1, SNAP2 and SNAP7 are displayed in Fig. 1. Note that the same diurnal profile is applied for all days of the week (Monday to Sunday) per SNAP category. These time profiles are applied to every country in the model domain. Except for agriculture, all time profiles were obtained in the early 1990s and have been used ever since. The traffic cycle is based on Dutch urban traffic counts, but the exact origin of the other profiles is not reproducible.

Application of these profiles was not limited to LOTOSEUROS, as they have been used within, for example, the MACC regional ensemble (Kuenen et al., 2011), AQMEII (Pouliot et al., 2012) and other model exercises (e.g., van Loon et al., 2004). Below, we describe how we replaced the temporal profiles for SNAP1, SNAP2 and SNAP7.

\subsection{SNAP7 - road transport}

So far, the default time profiles for road transport do not take into account the temporal release of emissions from road transport based on the driving behavior as a function of location, vehicle type and street type. To study this in more detail we used traffic count data for light-duty vehicles (LDV) and heavy-duty vehicles (HDV) at 12 highway stations and 6 urban street stations (Bundesstraßen) distributed across Germany for the years 2006-2010. First of all, we analyzed these data in view of differences between temporal variation in traffic patterns at highway and urban street locations and differences in the diurnal cycle for each day of the week. We found a considerable difference between the diurnal cycles on weekdays and weekends, with less pronounced rush hour peaks on Saturday and Sunday for both street types. Furthermore, the diurnal profiles for urban streets show much more pronounced morning and afternoon rush-hour peaks than highways. This is explained by the dominance of local commuter traffic on urban roads versus long-distance traffic on the highways. Also striking is that on highways, in 

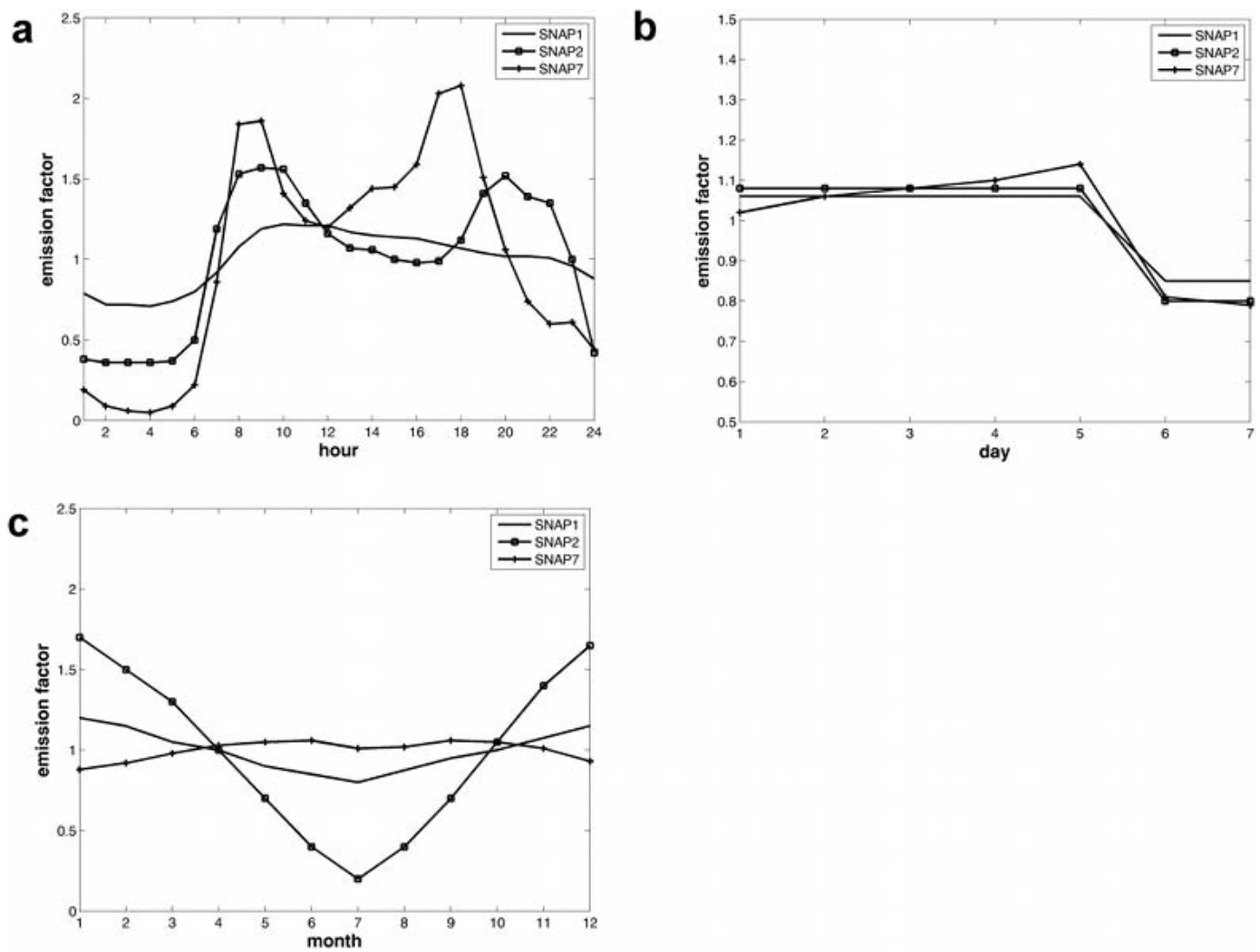

Fig. 1. Overview of the LOTOS-EUROS default diurnal cycle (a), weekly cycle (b) and seasonal cycle (c) of emission factors for the SNAP1, SNAP2 and SNAP7 categories.

contrast to urban streets, the total traffic counts are highest on a Friday and do not decrease during the weekend. However, when differentiating between vehicle types, HDV traffic counts on highways significantly decrease on the weekend. In terms of total counts, this decrease is compensated for by increased LDV traffic on highways.

Although there is a large correspondence between the temporal cycles among highway locations, individual stations show particular features. For instance, on highways near the north coast, traffic intensity shows peaks around the weekend (explained by weekend tourism), whereas, in contrast to all other sites, traffic on the highway between Germany and Austria shows a summer maximum due to increased longrange traffic during summer holidays. Hence, in order to be very detailed, a traffic model with specific data for all major roads or temporal profiles per road segment should be used. This is far too complicated for our purposes. Therefore, all traffic data were averaged across all urban and highways sites in order to obtain profiles that are representative of all German urban streets and highways. These profiles are based on annual profiles representing the emission factors per month and profiles representing every hour of the week. The annual profiles are constructed by averaging the available traffic count data for the urban and the highways per month and relating them to the total traffic in the year. The same has been done for every hour of the week. In Fig. 2, time series of the difference between actual traffic counts and the application of the default and the new urban and highway time profiles are given for an urban a highway station for the year 2010 . The urban and highway time profiles based on German traffic counts explain systematically more of the observed traffic counts at all stations than the default time profile as the residues are closer to zero. As the default time profiles are based on urban street traffic counts, this is especially striking for the highway station (Fig. 2b). Very high residues occur in March, May and at the end of December, related to holiday impacts (Easter, Whitsunday, Christmas), which are not explicitly considered in the profiles. Thus, considering the day of week and the road type helps in improving the description of the temporal driving patterns.

Going one step further, considering the large difference in temporal driving behavior and emissions from HDV and LDV traffic, separate profiles per vehicle type (LDV and HDV) on highways and urban streets were constructed by averaging the traffic count data per vehicle and road type over all 5 yr. Figure 3 a shows the diurnal traffic profiles per day of the week and the contribution of each category. Assuming that emissions for all vehicle and street types are the same, the black cycle would represent the total emission time profile. Obviously, traffic emissions are dependent on road 

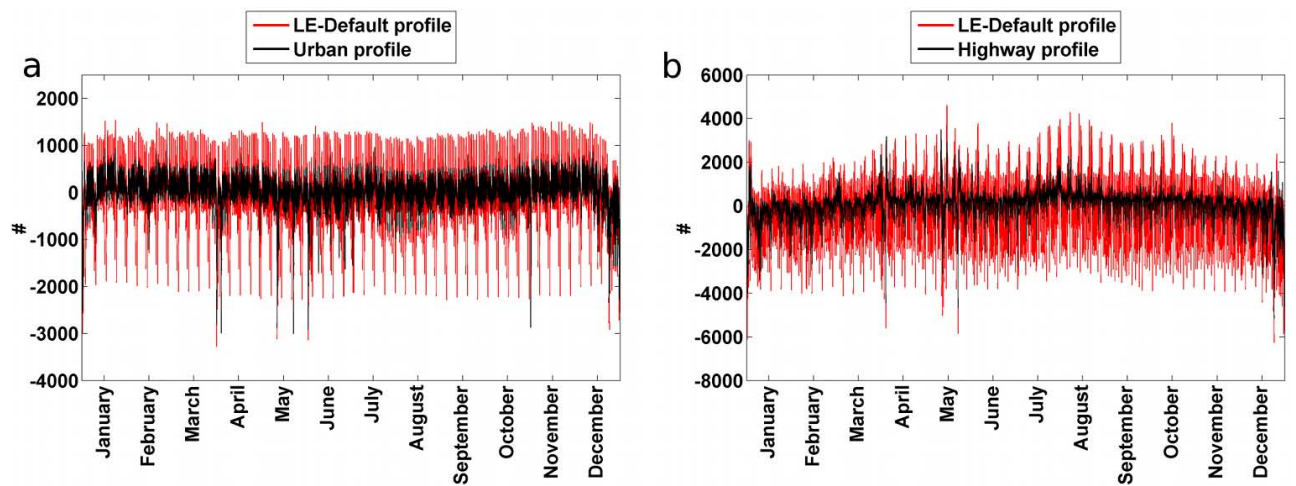

Fig. 2. Time series of the differences between actual traffic counts and the application of the default and the new urban and highway time profiles at an urban street station (Bottrop) (a) and a highway station (Lauenau) (b) in Germany for the year 2010.

a

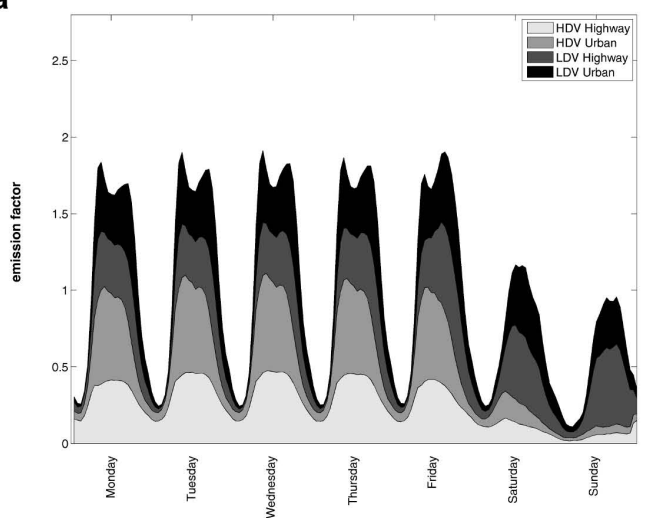

b

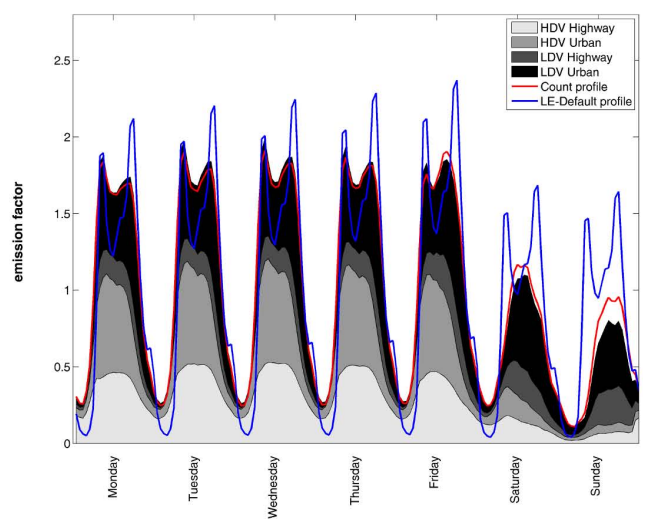

Fig. 3. Summation of diurnal cycles per day of the week for LDV and HDV on urban streets and highways equally weighted (a) and weighted with the $\mathrm{NO}_{\mathrm{x}}$ split factors (b). The red line (count profile) in (b) is the same as the black line in (a); the blue line represents the default time profiles.

(and vehicle) type (through fuel efficiency, which is dependent on speed and driving conditions) (Franco et al., 2013). To account for this feature, we used emission split factors that specify the fraction of emission per vehicle and street type in Germany to obtain an emission-weighted traffic profile. This split has been made using the underlying data in the TNO-MACC inventory, which is described in detail in Denier van der Gon et al. (2010). The split uses information from the IIASA RAINS model (Amann et al., 2005) for the differentiation in vehicle types and the TREMOVE model (De Ceuster et al., 2005) for differentiation in network types. The split implicitly takes different emission factors for different networks and vehicle types into account, as identified by the IIASA GAINS model and the TREMOVE model. The TNO spatial allocation procedure contains major highways on grid cells and by traffic intensity, which makes it possible to distribute highway emissions according to traffic intensity over the major highways, while emissions from urban and rural roads are distributed using population. From this result, for each grid cell the share of vehicle types and network types were determined. Note that the emission factors and thereby the importance of each of the four categories differs per pollutant. To account for this, $\mathrm{NO}_{\mathrm{x}}$ were chosen here because traffic has the largest contribution to this component (Table 1). Figure $3 \mathrm{~b}$ displays the diurnal traffic profiles per day of the week and the contribution of each category after emission strength weighting. It can be clearly seen that the contribution of emissions from the four categories is different, as, for example, in terms of emissions, the contribution from LDV on highways is much lower than in terms of number (Fig. 3a). A comparison between the unweighted, represented by the red line in Fig. 3b, and the weighted time cycles illustrates the effect of weighting the emission time profile by the $\mathrm{NO}_{\mathrm{x}}$ split factor. This effect is especially high on the weekend, when the weighted profiles are $\sim 20 \%$ lower.

This exercise showed that (1) an update of the time profiles with national data improves the comparison with traffic count data; (2) within a country, traffic regimes show differences; and (3) that the temporal variation for emissions differs from that of traffic counts and should ideally be computed for all species independently. Although not the focus here, the additional detail also allows for the 

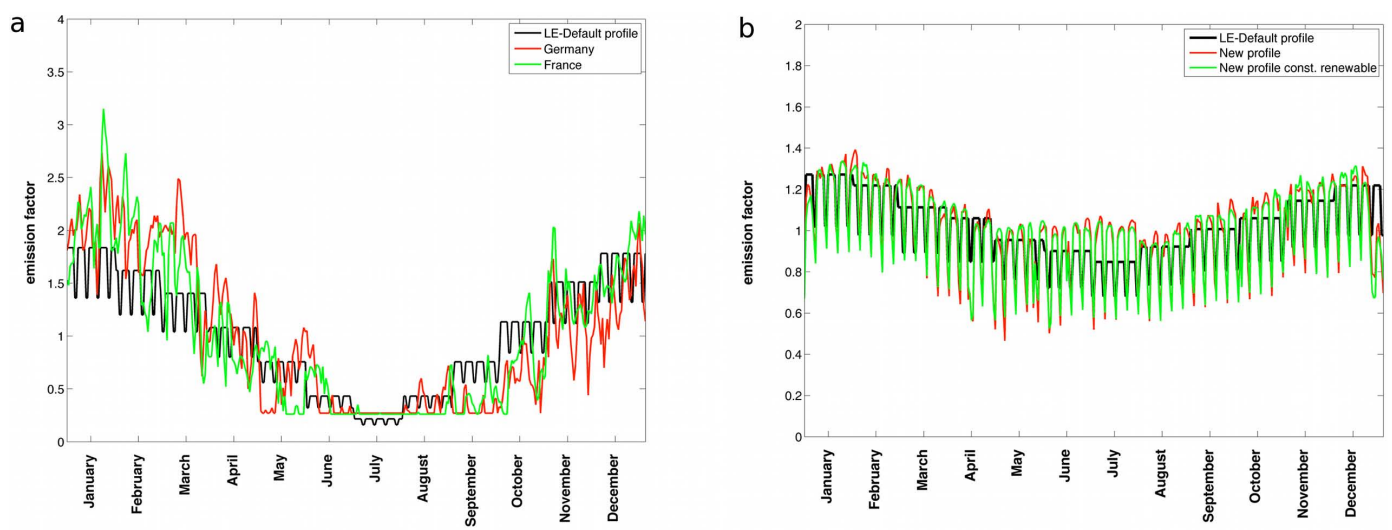

Fig. 4. Comparison between the new and the default seasonal (daily) emission factors for SNAP2 (a) retrieved from model grid cells located in Germany (longitude approximately $10^{\circ} \mathrm{E}$, latitude approximately $52.5^{\circ} \mathrm{N}$ ) and in France (longitude approximately $2.75^{\circ} \mathrm{W}$, latitude $^{\circ}$ approximately $43.75^{\circ} \mathrm{N}$ ) and for SNAP1 (b) for Germany.

technology-dependent composition of the emissions to be specified in more detail (e.g., VOC split and $\mathrm{NO}_{2} / \mathrm{NO}_{\mathrm{x}}$ fraction).

\subsection{SNAP2 - nonindustrial combustion}

The default time profile for nonindustrial combustion in LOTOS-EUROS reflects a strong (monthly) seasonal variation with a summer minimum. The default diurnal time profiles reflect the increased heating in the morning and evening to warm houses up as well as the cooking and warm water production activities when people are at home. Compared to residential houses, office buildings are more modern, cover a lower volume and are more efficient to heat, and therefore emission amounts are assumed to be lower during the day. As heating is turned down at night and other activities relevant for SNAP2 are much lower during this time, the emission factors show a minimum at that point in time. Country-specific information is only considered by national emission totals per component and not by the time profiles. The impacts of, for example, cold weather spells which increase the demand for heating are not accounted for. We applied new emission time profiles for SNAP2, which are based on the method used in the CHIMERE (Bessagnet et al., 2012) and EMEP models (Simpson et al., 2012). This method uses the concept of heating degree days, which is a measure designed to reflect the demand for energy needed to heat a building. The heating degree day factor $\left(H_{\mathrm{D}, \mathrm{C}}\right)$ is defined relative to a base temperature (outside temperature) above which a building needs no heating (here: $291.15 \mathrm{~K}$ ) $\left(H_{\mathrm{D}, \mathrm{C}}=\max \left(291.15 \mathrm{~K}-T_{\mathrm{D}, \mathrm{C}}, 1\right)\right)(1$ rather than 0 to avoid numerical problems). This factor increases with increasing difference between the actual $2 \mathrm{~m}$ daily mean outside temperature $T_{\mathrm{D}, \mathrm{C}}$ and the base temperature. The heating degree day factors are precalculated in the model per day and grid cell. The fraction $f$ of SNAP2 emissions not attributed to heating is a constant, assumed here to be $20 \%(f=0.2)$, and is multiplied by the yearly average of the heating degree days per grid cell $\left(\bar{H}_{\mathrm{C}}\right)$. In order to obtain to the SNAP2 emission factor $\left(F_{\mathrm{D}, \mathrm{C}}\right)$ the contribution from both terms are added $\left(D_{\mathrm{D}, \mathrm{C}}=H_{\mathrm{D}, \mathrm{C}}+f * \bar{H}_{C}\right)$ and related to the whole year by calculating an average factor $\overline{D_{C}},\left(\overline{D_{C}}=(1+f) * \bar{H}_{C}\right)$. $F_{\mathrm{D}, \mathrm{C}}=\frac{D_{\mathrm{D}, \mathrm{C}}}{\overline{D_{C}}}$ is then the daily SNAP2 emission factor per grid cell. In summertime, when the actual temperatures are close to or above the base temperature, the emission factor is very small, but in winter the factor is usually significant and can change quite substantially from day to day. To obtain to the hourly emission factors, the default diurnal emission profiles from LOTOS-EUROS (Fig. 1a) are used.

The resulting time profiles (Fig. 4a) show stronger temporal variations compared to the default LOTOS-EUROS profiles. Note that the calculations also induce a spatial variability within the country, with higher emission factors in regions experiencing a colder climate. At the beginning of the year in particular, the new emission factors are higher than the default factors. In the summer months both time profiles are very similar to each other because the scaling factor $f$, used in the new method, is close to the default summer emission factor. In the last four months the new time profiles are similar or lower, depending on the location. This described annual cycle of the new emission time profiles corresponds to the yearly cycle of the daily average temperature. In general, the temperature is lower in the first months of a year compared to the ones at the end of the year, which is not taken into account in the default time profiles but which is reflected in the new profiles.

\subsection{SNAP1 - combustion in energy and transformation industries}

The temporal variability of SNAP1 is assessed by focusing on the power generation sector, as the contribution of emissions from power plants dominates the total SNAP1 emission 
for all pollutants except NMVOC. As for the other sectors the default emission profiles for the power sector (SNAP1) are assumed to be the same across all countries and invariable with meteorology. This may not be the best representation of reality, since, for example,

- climate conditions may cause differences in seasonal profiles for countries across Europe,

- variations in electricity consumption (e.g., for heating/cooling) due to changes in meteorology during the year are not represented,

- variable social habits may induce shifts in diurnal cycles between countries.

Therefore, new time profiles for the power generation sector (SNAP1) were constructed for 2006 using electricity demand data from each country. The electricity demand data for the year 2006 have been obtained from the ENTSO-E, the European Network of Transmission System Operators for Electricity. These demand data (in MW) are country-specific time series of hourly data.

In Europe on average, $54 \%$ of the electricity is generated using fossil fuels (http://epp.eurostat.ec.europa.eu). Nuclear power and hydroelectric power account for 25 and $16 \%$, respectively. Intermittent renewable sources only produce a minor part of the total electricity demand $(3.7 \%$ for wind energy and $0.4 \%$ for solar power in EU27). Between countries, large differences in the electricity mix exist. For example, France has a much larger share of nuclear power than average, whereas the same applies to Norway, Austria and Switzerland with respect to hydropower. For Germany, the contribution of power generated using fossil fuels on the total electricity demand is on average $63.5 \%$, for nuclear and hydroelectric power it is $26 \%$ and $5.4 \%$, respectively, and the contribution of the intermittent renewable sources are $4.8 \%$ for wind and $0.3 \%$ for solar. Hence, intermittent sources represent a comparably small part of the electricity mix in Germany but should be considered also because they are expected to become more important.

As only fossil fuels cause emissions during electricity production, we made a limited effort to subtract the power that is generated from the non-fossil-fuel sources from the total electricity demand. Specific attention was paid to the role of intermittent renewables. For this purpose, we used the REMix model (Scholz, 2012). REMix is an energy system model that generates electricity supply systems based on electricity demand and an inventory of the maximum installable capacity of different electricity generating types and technologies, potential power generation for each hour of a specific year (for intermittent sources like solar and wind) and the costs of technologies. Based on these input parameters, the model can calculate the optimal mix of electricity generation sources based on the user request, e.g., finding the most economical solution or by using a fixed percentage of renewables. For this study, the REMix was used to calculate the time series of electricity production from solar and wind such that the installed capacity meets the annual contribution of the sources for each country.

For nuclear and hydropower, the electricity generation is assumed constant throughout the year. For nuclear electricity, this assumption is justified since nuclear power plants tend to run at constant capacity throughout the year, maintenance excluded. Hydroelectric power production, however, is highly variable over time because of water availability for run-off-river hydropower plants and because hydroelectric plants taking water from weir reservoirs are often used as an energy reservoir in times of low demand and electricity production is increased when demand peaks. The power output from hydroelectric plants can be adjusted to meet demand easily. However, as no data for the variability of hydroelectric power production over time were available, the admittedly crude assumption of constant production was made in this study. Hence, this is another reason why we focus the evaluation on Germany, where hydropower is less important.

By subtracting the time series of solar and wind energy production as well as the constant contributions of other electricity sources from the hourly demand data, an approximation of the hourly pattern for the fossil fuel emissions remains. These data are used in a relative way to distribute the annual emissions from fossil-fuel-based power plants over all hours in the year. The new seasonal time profile for Germany shows a stronger temporal variability between the months and weeks compared to the default LOTOS-EUROS profiles (Fig. 4b). The weekly cycle is more pronounced, with higher amplitude caused by higher emission factors during the week and decreased factors on the weekend. This is especially pronounced in the summer months, when emission at peak production is much higher than in the default profiles. Furthermore, the yearly minimum is shifted to spring and autumn months. Looking more closely at a summer week, the daily cycle for the new timing shows peak values in the morning and late afternoon, whereas the afternoon peak is not present in the base case (not shown).

In Fig. $4 \mathrm{~b}$ the impact of accounting for the intermittent renewable sources is quantified by comparing to the situation where wind and solar are assumed also to be constant. The day-to-day variability of the emission factors is slightly smaller when the renewables are assumed to have a constant production over the year, because meteorological characteristics causing the intermittency in renewable electricity production are not accounted for. The seasonal variability is hardly affected at all. Hence, considering the countryspecific electricity demand had a much larger impact on the new time profiles than when accounting for intermittent renewable electricity production.

For the generation of SNAP1 profiles, the implicit assumption made in this study is that the electricity generated within a country is used within the same country; that is, no crossborder transport of electricity is assumed. Another major 
a

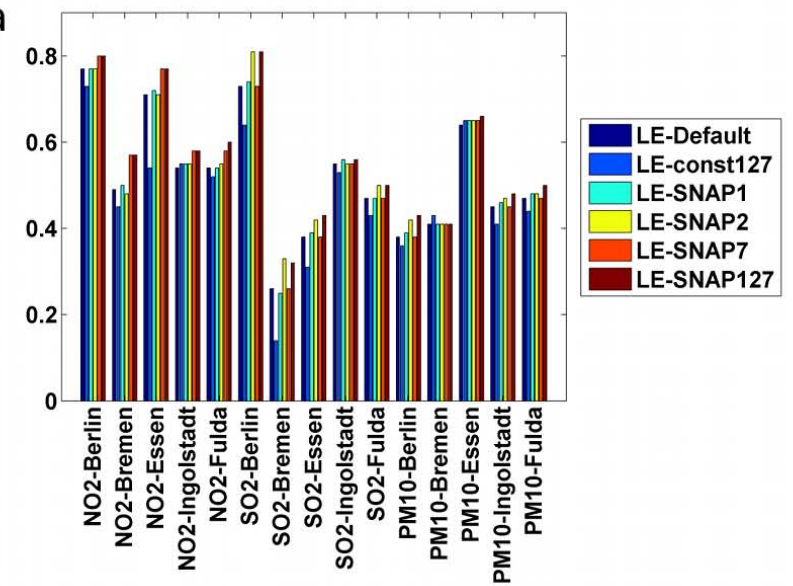

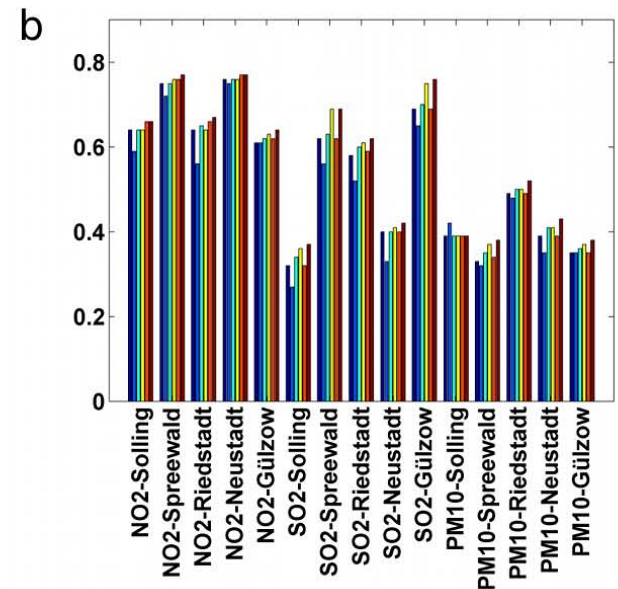

Fig. 5. Bar charts of the daily correlation coefficients for all simulations at selected urban (a) and rural (b) background stations across Germany.

assumption is that storage of electricity is excluded, meaning electricity that is produced within a certain hour needs to be used in that same hour. Combined with the assumption that hydroelectricity production is constant, this means that the variability in emission timing from fossil fuels used in this study is likely to be an overestimation of the variability in reality. Significant improvements in the time profiles for SNAP1 are possible with a much more detailed energy model.

The contribution of emissions from power plants dominates the total SNAP1 emission for most pollutants (except NMVOC). As an example, according to the German official emission inventory for the year 2005, $227 \mathrm{kt}$ of $\mathrm{SO}_{2}$ and $9.79 \mathrm{kt}$ of primary anthropogenic $\mathrm{PM}_{10}$ are emitted from power plants, whereas $63 \mathrm{kt}$ of $\mathrm{SO}_{2}$ and $1.59 \mathrm{kt}$ of primary $\mathrm{PM}_{10}$ come from other SNAP1 sources. In this study it is therefore assumed that the same profiles as those constructed for the power plants also apply for the other sources.

\section{Results}

In this section the results of the model simulations LE_const127 (Sect. 4.1), LE_SNAP7 (Sect. 4.2), LE_SNAP2 (Sect. 4.3), LE_SNAP1 (Sect. 4.4) and the combined run LE_SNAP127 (Sect. 4.5) are compared to the LE Default simulation and to measurements in order to test the sensitivity of the model to the new constructed time profiles. Tables 3 and 4 provide a statistical comparison of all simulations against observations for daily and hourly data, respectively. Figure 5 summarizes the temporal correlation coefficients for selected urban and rural stations, representing different parts of Germany.

\subsection{Constant profiles}

To demonstrate the impact of the default time profiles for SNAP 1,2 and 7 on pollution simulations with LOTOSEUROS, the LE_const127 simulation was carried out using constant emissions in time for these three SNAP categories. The largest impact of using profiles is found for $\mathrm{NO}_{2}$, with an average increase in the correlation coefficient of 0.22 and 0.14 for urban and rural background stations, respectively, when using the default profiles (Table 3). The increase in correlation coefficients on a daily basis is very modest in comparison (Table 4), showing the strong impact of accounting for the diurnal cycle of $\mathrm{NO}_{\mathrm{x}}$ emission from traffic. However, the size of the increase highly depends on the station and varies between -0.01 and 0.17 (Fig. 5). Neglecting the emission-induced part of the $\mathrm{NO}_{2}$ temporal variability in the LE_const127 simulation, and only considering the part resulting from meteorology and chemistry, leads to a diurnal cycle with a concentration maximum during the night, whereas the LE_Default simulation and the measurements show a nighttime minimum (not shown). The lower effective dilution leading to the nighttime maximum causes a $10 \%$ higher average $\mathrm{NO}_{2}$ surface concentration in the LE_const127 simulation (Tables 3, 4). For $\mathrm{SO}_{2}$ on an hourly basis an average increase in the correlation coefficient of 0.13 and 0.06 is found for urban and rural background stations, respectively (Table 3 ). In contrast to $\mathrm{NO}_{2}$, a very similar change in correlation was observed for the hourly and the daily time series, indicating a more equal relevance of diurnal, weekly and seasonal emission time profiles (Tables 3, 4). For $\mathrm{SO}_{2}$ no systematic impact on the annual mean concentration was shown (Tables 3,4). The smallest impacts of the default time profiles are found for $\mathrm{PM}_{10}$, and the change in correlation ranges between -0.03 and 0.04 depending on the stations (Fig. 5). 
Table 3. Statistical overview of model performance averaged over all available stations based on hourly data. Thirty rural background stations and 48 urban background stations are included in the statistics. Annual mean and bias are given in $\mu \mathrm{g} \mathrm{m}^{-3}$.

\begin{tabular}{|c|c|c|c|c|c|c|c|c|c|}
\hline \multicolumn{10}{|c|}{ Rural background stations } \\
\hline Simulation & \multicolumn{3}{|c|}{$\mathrm{NO}_{2}$} & \multicolumn{3}{|c|}{$\mathrm{SO}_{2}$} & \multicolumn{3}{|c|}{$\mathrm{PM}_{10}$} \\
\hline Name & Correlation & Annual mean & Bias & Correlation & Annual mean & Bias & Correlation & Annual mean & Bias \\
\hline LE_Default & 0.71 & 9.88 & -1.80 & 0.70 & 2.05 & -0.78 & 0.46 & 11.22 & -7.60 \\
\hline LE_const 127 & 0.57 & 11.17 & -0.51 & 0.64 & 2.01 & -0.82 & 0.46 & 11.22 & -7.60 \\
\hline LE_SNAP1 & 0.72 & 9.89 & -1.79 & 0.71 & 2.04 & -0.79 & 0.47 & 11.20 & -7.62 \\
\hline LE_SNAP2 & 0.71 & 9.91 & -1.77 & 0.74 & 2.08 & -0.75 & 0.47 & 11.25 & -7.58 \\
\hline LE_SNAP7 & 0.72 & 9.98 & -1.70 & 0.70 & 2.05 & -0.78 & 0.46 & 11.20 & -7.62 \\
\hline LE_SNAP127 & 0.73 & 10.02 & -1.66 & 0.74 & 2.07 & -0.76 & 0.48 & 11.20 & -7.62 \\
\hline \multicolumn{10}{|c|}{ Urban background stations } \\
\hline Simulation & \multicolumn{3}{|c|}{$\mathrm{NO}_{2}$} & \multicolumn{3}{|c|}{$\mathrm{SO}_{2}$} & \multicolumn{3}{|c|}{$\mathrm{PM}_{10}$} \\
\hline Name & Correlation & Annual mean & Bias & Correlation & Annual mean & Bias & Correlation & Annual mean & Bias \\
\hline LE_Default & 0.70 & 13.33 & -13.42 & 0.62 & 2.80 & -2.08 & 0.51 & 12.70 & -12.36 \\
\hline LE_const 127 & 0.48 & 15.15 & -11.60 & 0.49 & 2.76 & -2.12 & 0.49 & 12.75 & -12.31 \\
\hline LE_SNAP1 & 0.71 & 13.33 & -13.43 & 0.65 & 2.79 & -2.09 & 0.52 & 12.68 & -12.38 \\
\hline LE_SNAP2 & 0.70 & 13.35 & -13.41 & 0.67 & 2.83 & -2.05 & 0.52 & 12.73 & -12.33 \\
\hline LE_SNAP7 & 0.72 & 13.49 & -13.26 & 0.62 & 2.80 & -2.08 & 0.51 & 12.69 & -12.38 \\
\hline LE_SNAP127 & 0.72 & 13.51 & -13.25 & 0.69 & 2.83 & -2.06 & 0.53 & 12.69 & -12.37 \\
\hline
\end{tabular}

Table 4. Statistical overview of model performance averaged over all available stations based on daily data. Twenty-four rural background stations and 48 urban background stations are included in the statistics. Annual mean and bias are given in $\mu \mathrm{g} \mathrm{m}^{-3}$.

\begin{tabular}{|c|c|c|c|c|c|c|c|c|c|}
\hline \multicolumn{10}{|c|}{ Rural background stations } \\
\hline Simulation & \multicolumn{3}{|c|}{$\mathrm{NO}_{2}$} & \multicolumn{3}{|c|}{$\mathrm{SO}_{2}$} & \multicolumn{3}{|c|}{$\mathrm{PM}_{10}$} \\
\hline Name & Correlation & Annual mean & Bias & Correlation & Annual mean & Bias & Correlation & Annual mean & Bias \\
\hline LE_Default & 0.78 & 10.14 & -1.57 & 0.73 & 2.09 & -0.82 & 0.46 & 11.15 & -7.06 \\
\hline LE_const 127 & 0.76 & 11.55 & -0.15 & 0.67 & 2.06 & -0.86 & 0.47 & 11.16 & -7.06 \\
\hline LE_SNAP1 & 0.79 & 10.14 & -1.56 & 0.74 & 2.08 & -0.83 & 0.47 & 11.13 & -7.08 \\
\hline LE_SNAP2 & 0.78 & 10.17 & -1.54 & 0.76 & 2.12 & -0.79 & 0.48 & 11.18 & -7.04 \\
\hline LE_SNAP7 & 0.79 & 10.24 & -1.46 & 0.73 & 2.09 & -0.82 & 0.47 & 11.13 & -7.09 \\
\hline LE_SNAP127 & 0.80 & 10.28 & -1.42 & 0.76 & 2.12 & -0.80 & 0.49 & 11.13 & -7.08 \\
\hline \multicolumn{10}{|c|}{ Urban background stations } \\
\hline Simulation & \multicolumn{3}{|c|}{$\mathrm{NO}_{2}$} & \multicolumn{3}{|c|}{$\mathrm{SO}_{2}$} & \multicolumn{3}{|c|}{$\mathrm{PM}_{10}$} \\
\hline Name & Correlation & Annual mean & Bias & Correlation & Annual mean & Bias & Correlation & Annual mean & Bias \\
\hline LE_Default & 0.77 & 13.03 & -13.69 & 0.71 & 2.64 & -2.18 & 0.54 & 12.55 & -12.38 \\
\hline LE_const 127 & 0.73 & 14.84 & -11.88 & 0.60 & 2.60 & -2.22 & 0.53 & 12.59 & -12.34 \\
\hline LE_SNAP1 & 0.78 & 13.03 & -13.69 & 0.74 & 2.63 & -2.19 & 0.55 & 12.53 & -12.40 \\
\hline LE_SNAP2 & 0.77 & 13.05 & -13.67 & 0.76 & 2.67 & -2.14 & 0.56 & 12.58 & -12.35 \\
\hline LE_SNAP7 & 0.81 & 13.19 & -13.53 & 0.71 & 2.64 & -2.18 & 0.54 & 12.53 & -12.40 \\
\hline LE_SNAP127 & 0.82 & 13.20 & -13.52 & 0.78 & 2.66 & -2.15 & 0.57 & 12.54 & -12.39 \\
\hline
\end{tabular}

The findings in this section illustrate the importance of considering the temporal release of emissions in the model and its impact on the model performance. However, the impact shown here is limited by the quality of the emission time profiles used. Thus, below we assess the impact of using improved time profiles for SNAP 1, 2, and 7 separately.

\subsection{SNAP7 - Road transport}

On average the impact of using the new SNAP7 time profiles on the $\mathrm{NO}_{2}$ correlation coefficient is only small (0.01 to 0.04$)$ (Tables 3,4). But the increase in the correlation coefficient is found to vary between 0.01 and 0.08 at individual urban and rural background stations (Fig. 5). As a result of the higher 
a

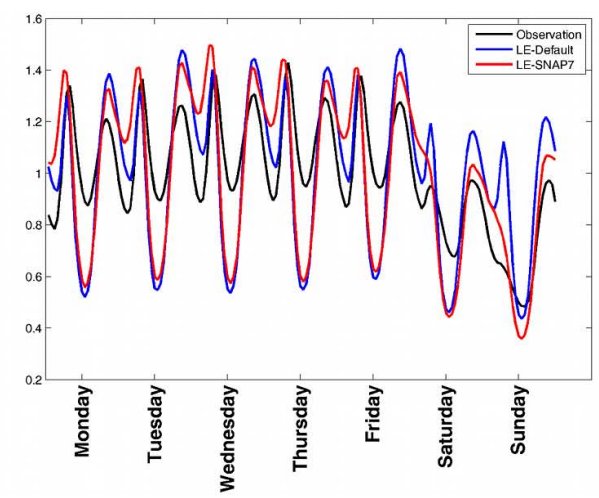

b

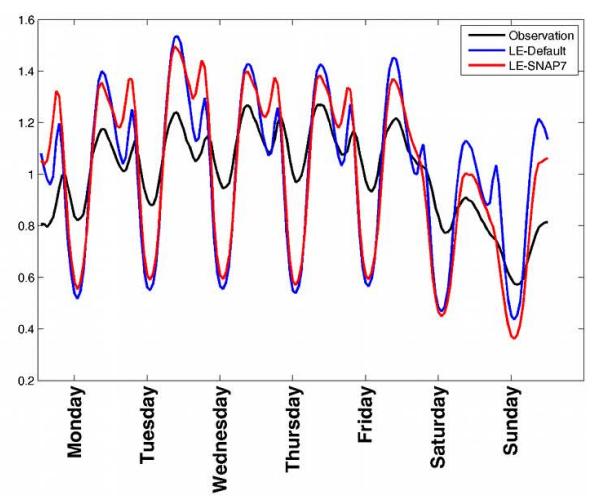

Fig. 6. Simulated and measured normalized weekly cycle of $\mathrm{NO}_{2}$ at all available urban (a) and rural (b) stations. Marks along the top show 12:00 LT.

relevance of $\mathrm{NO}_{\mathrm{x}}$ emissions from traffic in urban regions, the increase in correlation is found to be higher at urban (0.04) than at rural (0.01) stations (Table 3). The model bias for $\mathrm{NO}_{2}$ is found to decrease only slightly for the LE_SNAP7 simulation (Tables 3, 4). In Fig. 6 the measured and simulated (LE_Default and LE_SNAP7) averaged diurnal cycles per day of the week for $\mathrm{NO}_{2}$ at urban (a) and rural (b) background stations are displayed. Note that the cycles are normalized for a better comparison of the temporal variability. As discussed in Sect. 3.1 the strongest changes between the default and the new SNAP7 time profiles appear in the diurnal cycle on the weekend. An improved representation of the $\mathrm{NO}_{2}$ diurnal cycle on Saturday and Sunday is indeed found for the LE_SNAP7 simulation (Fig. 6). This includes a better reproduction of the measured lower concentration maxima in the morning on the weekend compared to weekdays. Furthermore, for the maxima in the evening, the LE_SNAP7 simulation is closer to the measurements. Overall, the LE_SNAP7 simulation is in better agreement with the lower measured $\mathrm{NO}_{2}$ concentration level on the weekend. During the week the LE_SNAP7 simulation shows higher concentrations for the minimum during the night compared to LE_Default and the measurements. This is due to more emitted mass during night and at early hours in the LE_SNAP7 simulation (see Fig. 3b). Furthermore at urban stations the measured maximum in the morning is higher than in the evening, whereas this is the other way around at rural stations. This feature is only captured by the LE_SNAP7 simulation, although differences between urban and rural regions are also not explicitly considered in the new SNAP7 profiles. These findings are verified by a higher correlation coefficient for the average weekly cycle for the LE_SNAP7 (e.g., 0.70 at urban stations) compared to the LE_Default simulation (0.64).

Both model simulations (LE_Default and LE_SNAP7) overestimate the measured $\mathrm{NO}_{2}$ amplitude in the diurnal cycle (Fig. 6), with maxima in the morning and evening that are too high as well as a minimum at noon that is too low. The explanation for the different behavior lies in the measurement technique applying molybdenum converters used to monitor $\mathrm{NO}_{2}$ in Germany (and other networks in Europe). Evaluation of instruments using molybdenum converters against photolytic converters has shown that the molybdenum converters also convert part of the NOy (Dunlea et al., 2007; Steinbacher et al., 2007). These components maximize during daytime, causing up to a factor of 2 difference in measured $\mathrm{NO}_{2}$ during the afternoon (Villena et al., 2012). To illustrate the impact of the monitoring method, we use two 3 yr time series of simultaneous measurements covering 2006-2009 at the site Payerne in Switzerland. A systematic difference in measured $\mathrm{NO}_{2}$ concentration is indeed found for the two measurement techniques (Fig. 7). The normalized weekly cycles for the instruments show a stronger amplitude for the photolytic converter, with both lower minima and higher maxima in the morning. The size of the interference is variable as it depends on the NOy-to- $\mathrm{NO}_{2}$ ratio and therefore on season, pollution regime $\left(\mathrm{NO}_{2}\right.$, oxidant levels), air mass age, etc. Thus, the extent of the difference found for the station Payerne cannot be directly translated to the German stations used here. In summary, the monitoring technique explains part of the difference between the measured and simulated $\mathrm{NO}_{2}$ diurnal cycle. Note that the measurement technique may also partly explain why the higher amplitude at urban stations compared to rural stations is not captured, as the NOy-to- $\mathrm{NO}_{2}$ ratio is expected to be higher at rural areas than in urban environments.

In short, the new SNAP7 time profiles provide an improvement compared to the default profiles. As one can expect, the average impact is not as large as found in Sect. 4.1, but at some stations the improvement in the $\mathrm{NO}_{2}$ correlation coefficient is in the same range as found for the LE_Default simulation compared to LE_const127. The important improvements in the explained variability over the weekdays as well as the diurnal cycle are observed. 


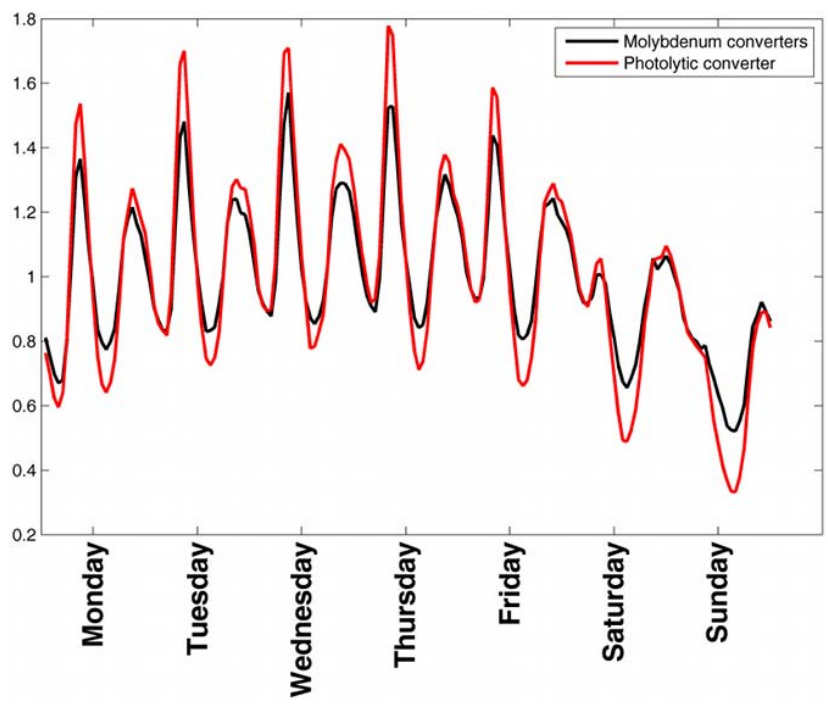

Fig. 7. Normalized weekly cycle of $\mathrm{NO}_{2}$ of simultaneous measurements using a molybdenum converter and a photolytic converter averaged over a 3 yr time series (2006-2009) at the site Payerne in Switzerland.

\subsection{SNAP2 - nonindustrial combustion}

When introducing the heating degree day dependent time profiles of nonindustrial combustion (SNAP2), an average increase in daily correlation for $\mathrm{SO}_{2}$ at urban $(0.03)$ and rural (0.05) stations is found for the LE_SNAP2 simulation (Table 4). The size of the increase depends on the location and shows a positive southwest to northeast gradient across stations in Germany, with a rise of up to 0.08 compared to LE_Default in the east of the domain (Fig. 8a). The fact that this is found for both urban and rural stations hints at a considerable contribution of SNAP2 $\mathrm{SO}_{2}$ emissions to the total $\mathrm{SO}_{2}$ concentration from long-range transport processes rather than from the different contribution in rural and urban regions. $\mathrm{SO}_{2}$ emissions from SNAP2 are considerably higher in regions east of the domain due to heating systems with still a high share of coal and wood use (Kuenen et al., 2011). The use of different fuels (e.g., gas, coal) for heating systems within one country is not accounted for in the spatial distribution of the SNAP2 emissions. In fact, the total amount of emissions is weighted by the population density in a grid cell. Thus the slightly higher impact of the new SNAP2 emission profiles at urban stations (Tables 3,4 ) suggests a higher contribution of $\mathrm{SO}_{2}$ emissions from the SNAP2 category in urban than in rural areas. The difference between the default and the new constructed time profiles for SNAP2 is highest during the months January to March (Fig. 4). At urban stations the average correlation coefficient for $\mathrm{SO}_{2}$ for this period is smaller for both the LE_Default $(0.57)$ and the LE_SNAP2 (0.6) simulations compared to the results for the whole year presented in Table 3. Thus the increase in the correlation for this short period is comparable to that for the whole year. A small increase in correlation and decrease in the model bias is also found for PM $_{10}$ for the LE_SNAP2 compared to the LE_Default simulation (Fig. 5; Tables 3, 4). Applying the new approach for SNAP2 in the model results in a systematic increase in the model performance, including the consideration of local features.

\subsection{SNAP1 - combustion in energy and transformation industries}

The impact of the new SNAP1 profiles on the correlation coefficient for $\mathrm{SO}_{2}$ is on average only modest, with an increase of 0.03 at urban and of 0.01 at rural stations (Tables 3,4) but higher at some individual stations (Fig. 8b). The locations of coal-fired power stations in Germany are mainly concentrated in the west of the domain. A slightly higher increase in correlation for $\mathrm{SO}_{2}$ between 0.04 and 0.08 is indeed found in the southwest of the domain, whereas the increase in the east is only modest (0.02), hinting at a local impact of the SNAP1 profiles. The effect of the new time profiles on the $\mathrm{SO}_{2}$ mean concentration and the model performance for $\mathrm{NO}_{2}$ and $\mathrm{PM}_{10}$ is only low (Tables 3,4 ).

\subsection{Combined run (LE_SNAP127)}

The largest increase in the average correlation coefficient is found if all three new time profiles are used simultaneously in one simulation (LE SNAP127). The size of the increase depends on the component and is mainly dominated by the most relevant SNAP category for the component. Thus for $\mathrm{NO}_{2}$ the increase is mainly determined by the SNAP7 profiles and ranges on average from 0.02 to 0.05 (Tables 3, 4). For $\mathrm{SO}_{2}$ the correlation coefficient on daily basis increases with 0.03 and 0.07 at rural and urban stations, respectively (Table 4). For $\mathrm{SO}_{2}$ the impact of both the SNAP1 and SNAP2 time profiles is noticeable, but at most stations the correlation coefficient is the same as for the LE_SNAP2 simulation (Fig. 5). Compared to every other simulation, LE_SNAP127 shows the highest increase in the correlation coefficient for $\mathrm{PM}_{10}$ compared to LE_Default, hinting that profiles from all SNAP categories are relevant for $\mathrm{PM}_{10}$. The increase is 0.03 and 0.02 based on daily and hourly data, respectively (Tables 3,4$)$. Overall the impact on the mean concentrations is only modest for all components.

\section{Discussion and conclusion}

In the present study the performance of LOTOS-EUROS was found to be sensitive to the temporal distribution of emissions. This was first indicated by an improvement in the model performance when using the LOTOS-EUROS default time profiles instead of constant emissions for the categories SNAP1, 2 and 7. In a second step, new and more detailed emission time profiles for the three emission categories were tested in the model. Separately, each new profile increased 
a

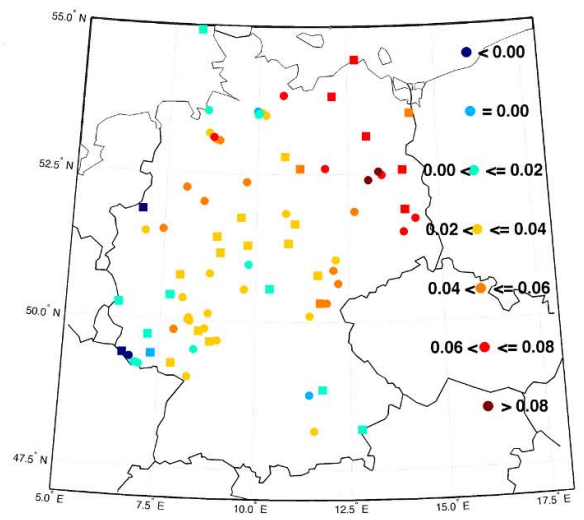

b

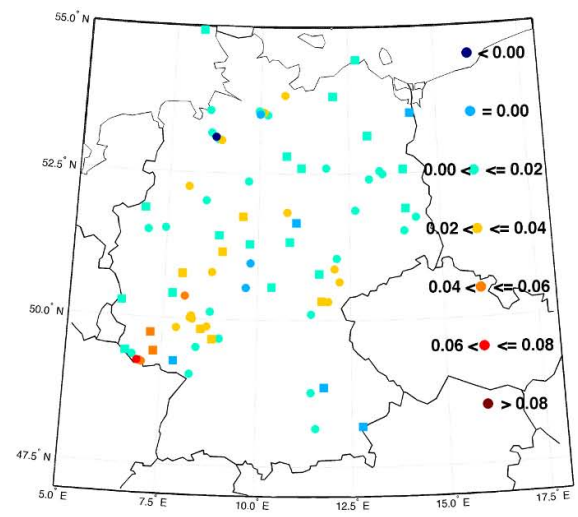

Fig. 8. Difference of daily correlation coefficient for $\mathrm{SO}_{2}$ between the model simulations using the new (LE_SNAP2, LE_SNAP1) and the default (LE_Default) emission time profiles for SNAP2 (a) and SNAP1 (b) across German urban (circle) and rural (squares) stations.

the model statistics compared to the default case. The highest improvement in model performance was found for the simulation using the three new profiles simultaneously. The improvement was found to be systematic, which gives confidence in the robustness of the results.

The correlation coefficient was used as a measure for the presentation of the temporal variability of simulated concentrations in the model. The size of the change in the correlation coefficient between the default and the other simulations depends on the SNAP category, the pollutant, the stations (urban, rural) and the time series (hourly, daily). On average an increase between 0.02 and 0.07 for the combined run (LE_SNAP127) compared to the default run (LE_Default) was found for Germany. To assess whether this impact is significant, we compare it to impacts of other model parameters. The impact of improving process descriptions on the correlation coefficient is generally low. For example, using different sea salt emission schemes led to a change in the correlation coefficient in the range of 0.00 to 0.05 at different stations in Europe (Schaap et al., 2009). Furthermore, implementation of a bidirectional surface-atmosphere exchange module for ammonia in the LOTOS-EUROS model in general did not affect the correlation for ammonia (Wichink Kruit et al., 2012). Comparing the performance from LOTOS-EUROS v1.6 to v1.8 (three years of development) shows lower impacts of model development on primary components than found here, whereas the improvement for PM is larger. Another way to assess the significance of the reported improvement due to the emission temporal profiles is to compare the spread between model performances of different models. The following examples, taken from the literature, show that the maximum difference of correlation coefficients between individual CTMs is normally larger than the impact of the improved emission profiles. However, these model comparison studies often show several models with very similar correlation coefficients. Stern et al. (2008) computed the correlation coefficients for five different regional CTMs for a winter period in 2003. For $\mathrm{SO}_{2}$ four models showed correlation coefficients within a range of 0.03. Van Loon et al. (2004) reported five out of six models within $0.04,0.1$ and 0.13 for $\mathrm{NO}_{2}, \mathrm{SO}_{2}$ and $\mathrm{PM}_{10}$, respectively. Van Loon et al. $(2004,2007)$ compared the model performance for ozone of seven regional CTMs for 2001 and found that correlation coefficients differed between 0.01 and 0.1 between individual models. In an air quality trend study for Europe by Colette et al. (2011), the performances of six regional and global chemistry transport models were compared. The model performances were tested at suburban stations over $10 \mathrm{yr}$ on the daily mean basis. For $\mathrm{NO}_{2}$ four of the six models showed a correlation coefficient between 0.57 and 0.66 , for ozone four models have a correlation between 0.74 and 0.8 , and for $\mathrm{PM}_{10}$ three out of four models show a correlation in the range of $0.53-0.57$. These comparisons indicate that the improvement using the new emission time profiles in the model is significant compared to the impact of other model developments in one model and to the range of model performance between different models.

This sensitivity study also provides information on the importance of the individual emission time profile (diurnal, weekly, seasonal cycle) per SNAP category to the different components. This is, for example, a strong impact of accounting for the diurnal cycle of $\mathrm{NO}_{\mathrm{x}}$ emission from traffic on the $\mathrm{NO}_{2}$ concentrations, as was also found by de Meij et al. (2006). Replacing the default (Dutch) profiles with national (German) representative profiles yielded important improvements in the explained variability over the weekdays as well as the diurnal cycle, which was also found by Pierce et al. (2010) and Menut et al. (2012). The largest impacts of the SNAP1 and 2 profiles were found for $\mathrm{SO}_{2}$. The importance of SNAP2 for $\mathrm{SO}_{2}$ was highlighted as the impact in eastern Germany was high and may deserve more attention. The improvement in the correlation coefficient for $\mathrm{SO}_{2}$ is higher in the LE_SNAP2 simulation than in that of LE_SNAP1, which is counterintuitive as the SNAP1 contribution to total $\mathrm{SO}_{2}$ emissions is higher than for SNAP2. Part of the explanation could be the application of the SNAP1 profiles to a limited number of point sources of which the impact at ground level 
is lower per unit emission than for area sources. In addition, the small improvement due to the new SNAP1 profiles hints that the default SNAP1 profiles may be quite reasonable for the sector. This is supported by the low change in profiles as illustrated in Fig. 4b. The smallest impact of the temporal profiles was found for $\mathrm{PM}_{10}$ in line with earlier studies (de Meij et al., 2006; Wang et al., 2010). The low impact can be explained by (1) a contribution of only $34.8 \%$ of considered SNAP categories to the primary $\mathrm{PM}_{10}$ emissions, (2) a relatively long life time and therefore high background concentration, (3) a large secondary fraction of $\mathrm{PM}_{10}$ increasing the dependence on process descriptions, and (4) a large model underestimation of the total mass due to missing components as secondary organic aerosol.

Although not within the scope of this study, but another important issue for the release of emissions in the model is the vertical distribution to the model layers. Wang et al. (2010) showed in a study of eastern Asia that, for example, the vertical distribution of emissions plays an essential role for $\mathrm{NO}_{2}$ and $\mathrm{SO}_{2}$. Another important aspect is to test the impact of the time profiles on the model performance as a function of the horizontal grid resolution. The representativeness of urban background stations increases with the grid resolution, and therefore also the impact of more detailed emission time profiles could increase especially for the SNAP categories 2 and 7 .

The findings presented in this explorative study show that a good description of the temporal variability of emissions in chemistry transport models is important and requires further attention. Even though the time profiles presented here for Germany already take more detailed information on temporal emission characteristics into account, a systematic effort is needed to generate time profiles for the different source categories for each European country. It is important to obtain these profiles at a subsector level, as illustrated for heavy- and light-duty traffic. Moreover, different emission processes should be differentiated and treated separately such as gasoline evaporation, exhaust emissions and resuspension. For the energy sector the variability of the energy mix in time should be incorporated as coal- and gasfired power plants have a different use in the energy system; in addition, cooking and heating should be differentiated for households. Where possible and relevant, the impact of meteorology should be incorporated. For example, meteorological conditions (rain events, snow) have an effect on observed traffic intensity (Cools et al., 2010). Hence, future emission inventories should contain more detailed information than just SNAP level 1 categories. Moreover, it is anticipated that specific modules should be developed to describe the emission variability per sector. An example is the ammonia emission module accounting for the dependency of agricultural practice as a function of location and meteorology, as described by Skjøth et al. (2011). Improved emission modules would provide an improved basis for air quality and climate scenarios, air quality forecasting and emission inversion studies.

In short, to improve a CTM performance in terms of the explained variability of simulated pollutant concentrations, it is recommendable to better represent the distribution of anthropogenic emission in time by developing a dynamical emission model taking into account regional specific factors and meteorology.

Acknowledgements. We would like to thank the German Bundestanstalt für Straßenwesen (BASt) for providing the traffic count data. Furthermore, this work was financially supported by TNO and has partly been funded by the FP7 project EnerGEO (see http://www.energeo-project.eu). We thank the reviewers for their constructive comments.

Edited by: B. Vogel

\section{References}

AIRBASE: European Topic Centre on Air and Climate Change, available at: http://acm.eionet.europa.eu/databases/airbase (last access: April 2013), 2012.

Amann, M., Bertok, I., Cabala, R., Cofala, J., Heyes, C., Gyarfas, F., Klimont, Z., Schöpp, W., and Wagner, F.: A further emission control scenario for the Clean Air For Europe (CAFE) programme, International Institute for Applied Systems Analysis (IIASA), http://ec.europa.eu/environment/ archives/cafe/activities/pdf/cafe_scenario_report_7.pdf, (last access: January 2014), 2005.

Banzhaf, S., Schaap, M., Kerschbaumer, A., Reimer, E., Stern, R., van der Swaluw, E., and Builtjes, P. J. H.: Implementation and evaluation of $\mathrm{pH}$-dependent cloud chemistry and wet deposition in the chemical transport model REM-Calgrid, Atmos. Environ., 49, 378-390, 2012.

Bessagnet, B., Terrenoire, E., Tognet, F., Rouïl, L., Colette, A., Letinois, L., and Malherbe, L. (eds.): The CHIMERE Atmospheric Model, EC4MACS Modelling Methodology, Report, 2012.

Builtjes, P. J. H., van Loon, M., Schaap, M., Teeuwisse, S., Visschedijk, A. J. H., and Bloos, J. P.: Project on the modelling and verification of ozone reduction strategies: contribution of TNOMEP, TNO-report, MEP-R2003/166, Apeldoorn, the Netherlands, 2003.

Castellanos, P., Stehr, J. W., Dickerson, R. R., and Ehrman, S. H.: The sensitivity of modeled ozone to the temporal distribution of point, area, and mobile source emissions in the eastern United States, Atmos. Environ., 43, 4603-4611, 2009.

Colette, A., Granier, C., Hodnebrog, Ø., Jakobs, H., Maurizi, A., Nyiri, A., Bessagnet, B., D’Angiola, A., D’Isidoro, M., Gauss, M., Meleux, F., Memmesheimer, M., Mieville, A., Rouill, L., Russo, F., Solberg, S., Stordal, F., and Tampieri, F.: Air quality trends in Europe over 20 the past decade: a first multimodel assessment, Atmos. Chem. Phys., 11, 11657-11678, doi:10.5194/acp-11-11657-2011, 2011. 
Cools, M., Moons, E., and Wets, G.: Assessing the impact of weather on traffic intensity, Weather, Climate, and Society, 2, 60$68,2010$.

Cuvelier, C., Thunis, P., Vautard, R., Amann, M., Bessagnet, B., Bedogni, M., Berkowicz, R., Brandt, J., Brocheton, F., Builtjes, P., Coppalle, A., Denby, B., Douros, G., Graf, A., Hellmuth, O., Honoré, C., Hodzic, A., Jonson, J., Kerschbaumer, A., de Leeuw, F., Minguzzi, E., Moussiopoulos, N., Pertot, C., Pirovano, G., Rouil, L., Schaap, M., Stern, R., Tarrason, L., Vignati, E., Volta, M., White, L., Wind, P., and Zuber, A.: CityDelta: a model intercomparison study to explore the impact of emission reductions in European cities in 2010, Atmos. Environ., 41, 189-207, 2007.

De Ceuster, G., Franck, L., van Herbruggen, B., Logghe, S., van Zeebroeck, B., Tastenhoye, S., Proost, S., Knockaert, J., Williams, I., Deane, G., Martino, A., and Firello, D.: TREMOVE 2.30 Model and Baseline description. Final report, available at: http://www.tremove.org (last access: January 2014), Transport and Mobility Leuven, 18 February 2005.

de Meij, A., Krol, M., Dentener, F., Vignati, E., Cuvelier, C., and Thunis, P.: The sensitivity of aerosol in Europe to two different emission inventories and temporal distribution of emissions, Atmos. Chem. Phys., 6, 4287-4309, doi:10.5194/acp-6-4287-2006, 2006.

Denier van der Gon, H. A. C., Visschedijk, A., van den Brugh, H., and Dröge, R.: F\&E Vorhaben: "Strategien zur Verminderung der Feinstaubbelastung" - PAREST: a high resolution European emission data base for the year 2005, TNO-Report, TNO-034UT-2010-01895 RPT-ML, Utrecht, 2010.

Dunlea, E. J., Herndon, S. C., Nelson, D. D., Volkamer, R. M., San Martini, F., Sheehy, P. M., Zahniser, M. S., Shorter, J. H., Wormhoudt, J. C., Lamb, B. K., Allwine, E. J., Gaffney, J. S., Marley, N. A., Grutter, M., Marquez, C., Blanco, S., Cardenas, B., Retama, A., Ramos Villegas, C. R., Kolb, C. E., Molina, L. T., and Molina, M. J.: Evaluation of nitrogen dioxide chemiluminescence monitors in a polluted urban environment, Atmos. Chem. Phys., 7, 2691-2704, doi:10.5194/acp-7-2691-2007, 2007.

Flemming, J., Inness, A., Flentje, H., Huijnen, V., Moinat, P., Schultz, M. G., and Stein, O.: Coupling global chemistry transport models to ECMWF's integrated forecast system, Geosci. Model Dev., 2, 253-265, doi:10.5194/gmd-2-253-2009, 2009.

Fountoukis, C. and Nenes, A.: ISORROPIA II: a computationally efficient thermodynamic equilibrium model for $\mathrm{K}^{+}$$\mathrm{Ca}^{2+}-\mathrm{Mg}^{2+}-\mathrm{NH}_{4}^{+}-\mathrm{Na}^{+}-\mathrm{SO}_{4}^{2-}-\mathrm{NO}_{3}^{-}-\mathrm{Cl}^{-2}-\mathrm{H}_{2} \mathrm{O}$ aerosols, Atmos. Chem. Phys., 7, 4639-4659, doi:10.5194/acp-7-4639-2007, 2007.

Franco, V., Kousoulidou, M., Muntean, M., Ntziachristos, L., Hausberger, S., and Dilara, P.: Road vehicle emission factors development: a review, Atmos. Environ., 70, 84-97, 2013.

Hass, H., Builtjes, P. J.H, Simpson, D., and Stern, R.: Comparison of model results obtained with several European regional air quality models, Atmos. Environ., 31, 3259-3279, 1997.

Hass, H., van Loon, M., Kessler, C., Stern, R., Matthijsen, J., Sauter, F., Zlatev, Z., Langner, J., Foltescu, V., and Schaap, M.: Aerosol Modelling: Results and Intercomparison from European Regional-scale Modelling Systems, EUROTRAC-2 Special report, Eurotrac-ISS, Garmisch Partenkirchen, Germany, 2003.

Hendriks, C., Kranenburg, R., Kuenen, J., van Gijlswijk, R.,Wichink Kruit, R., Segers, A., Denier van der Gon, H., and
Schaap, M.: The origin of ambient particulate matter concentrations in the Netherlands, Atmos. Environ., 69, 289-303, 2013.

Kaiser, J., Suttie, M., Flemming, J., Morcrette, J. J., Boucher, O., and Schultz, M.: Global realtime fire emission estimates based on space-borne fire radiative power observations, in: AIP Conf. Proc., 1100, 645-648, 2009.

Kranenburg, R., Segers, A. J., Hendriks, C., and Schaap, M.: Source apportionment using LOTOS-EUROS: module description and evaluation, Geosci. Model Dev., 6, 721-733, doi:10.5194/gmd6-721-2013, 2013.

Kuenen, J., Denier van der Gon, H., Visschedijk, A., van der Brugh, H., and van Gijlswijk, R.: MACC European emission inventory for the years 2003-2007, TNO report, TNO-060-UT-201100588, Utrecht, 2011.

Kukkonen, J., Olsson, T., Schultz, D. M., Baklanov, A., Klein, T., Miranda, A. I., Monteiro, A., Hirtl, M., Tarvainen, V., Boy, M., Peuch, V.-H., Poupkou, A., Kioutsioukis, I., Finardi, S., Sofiev, M., Sokhi, R., Lehtinen, K. E. J., Karatzas, K., San José, R., Astitha, M., Kallos, G., Schaap, M., Reimer, E., Jakobs, H., and Eben, K.: A review of operational, regionalscale, chemical weather forecasting models in Europe, Atmos. Chem. Phys., 12, 1-87, doi:10.5194/acp-12-1-2012, 2012.

Li, R., Wiedinmyer, C., Baker, K. R., and Hannigan, M. P.: Characterization of coarse particulate matter in the western United States: a comparison between observation and modeling, Atmos. Chem. Phys., 13, 1311-1327, doi:10.5194/acp-13-13112013, 2013.

Mårtensson, E. M., Nilsson, E. D., de Leeuw, G., Cohen, L. H., and Hansson, H.-C.: Laboratory simulations and parameterization of the primary marine aerosol production, J. Geophys. Res., 108, 4297, doi:10.1029/2002JD002263, 2003.

Menut, L., Goussebaile, A., Bessagnet, B., Khvorostiyanov, D., and Ung, A.: Impact of realistic hourly emissions profiles on air pollutants concentrations modelled with CHIMERE, Atmos. Environ., 49, 233-244, 2012.

Monahan, E. C., Spiel, D. E., and Davidson, K. L.: A model of marine aerosol generation via whitecaps and wave disruption, in: Oceanic Whitecaps and Their Role in Air/Sea Exchange, edited by: Monahan, E. C. and Mac Niocaill, G., D. Reidel, Norwell, Mass., USA, 167-174, 1986.

Mues, A., Manders, A., Schaap, M., Kerschbaumer, A., Stern, R., and Builtjes, P.: Impact of the extreme meteorological conditions during the summer 2003 in Europe on particulate matter concentrations, Atmos. Environ., 55, 377-391, 2012.

Peylin, P., Houweling, S., Krol, M. C., Karstens, U., Rödenbeck, C., Geels, C., Vermeulen, A., Badawy, B., Aulagnier, C., Pregger, T., Delage, F., Pieterse, G., Ciais, P., and Heimann, M.: Importance of fossil fuel emission uncertainties over Europe for $\mathrm{CO} 2$ modeling: model intercomparison. Atmos. Chem. Phys., 11, 66076622, doi:10.5194/acp-11-6607-2011, 2011.

Pierce, T., Hogrefe, C., Rao, T. S., Porter, P. S., and Ku, J. Y.: Dynamic evaluation of a regional air quality model: assessing the emissions-induced weekly ozone cycle, Atmos. Environ., 44, 3583-3596, 2010.

Pouliot, G., Pierce, T., Denier van der Gon, H., Schaap, M., Moran, M., and Nopmongcol, U.: Comparing emission inventories and model-ready emission datasets between Europe and North America for the AQMEII project, Atmos. Environ., 53, 4-14, 2012. 
Schaap, M., van Loon, M., ten Brink, H. M., Dentener, F. J., and Builtjes, P. J. H.: Secondary inorganic aerosol simulations for Europe with special attention to nitrate, Atmos. Chem. Phys., 4, 857-874, doi:10.5194/acp-4-857-2004, 2004a.

Schaap, M., Denier van der Gon, H. A. C., Dentener, F. J., Visschedijk, A. J. H., van Loon, M., ten Brink, H. M., Putaud, J.-P., Guillaume, B., Liousse, C., and Builtjes, P. J. H.: Anthropogenic black carbon and fine aerosol distribution over Europe, J. Geophys. Res., 109, D18201, doi:10.1029/2003JD004330, 2004b

Schaap, M., Timmermans, R. M. A., Sauter, F. J., Roemer, M., Velders, G. J. M., Boersen, G. A. C., Beck, J. P., and Builtjes, P. J. H.: The LOTOS-EUROS model: description, validation and latest developments, Int. J. Environ. Pollut., 32, 270-289, 2008.

Schaap, M., Manders, A., Hendriks, E. C. J., Cnossen, J. M., Segers, A. J., Denier van der Gon, H. A. C., Jozwicka, M., Sauter, F. J., Velders, G. J. M., Matthijsen, J., and Builtjes, P. J. H.: Regional modeling of particulate matter for the Netherlands, BOP report 500099008, 2009.

Scholz, Y.: Renewable energy based electricity supply at low costs - development of the REMix model and application for Europe, Dissertation, University of Stuttgart, Stuttgart, 2012.

Simpson, D., Fagerli, H., Jonson, J. E., Tsyro, S., Wind, P., and Tuovinen, J.-P.: Transboundary Acidification, Eutrophication and Ground Level Ozone in Europe, Part 1: Unified EMEP Model Description, EMEP Report 1/2003, Norwegian Meteorological Institute, Oslo, Norway, 2003.

Simpson, D., Benedictow, A., Berge, H., Bergström, R., Emberson, L. D., Fagerli, H., Flechard, C. R., Hayman, G. D., Gauss, M., Jonson, J. E., Jenkin, M. E., Nyíri, A., Richter, C., Semeena, V. S., Tsyro, S., Tuovinen, J.-P., Valdebenito, Á., and Wind, P.: The EMEP MSCW chemical transport model - technical description, Atmos. Chem. Phys., 12, 7825-7865, doi:10.5194/acp-12-78252012, 2012.

Skjøth, C. A., Geels, C., Berge, H., Gyldenkærne, S., Fagerli, H., Ellermann, T., Frohn, L. M., Christensen, J., Hansen, K. M., Hansen, K., and Hertel, O.: Spatial and temporal variations in ammonia emissions - a freely accessible model code for Europe, Atmos. Chem. Phys., 11, 5221-5236, doi:10.5194/acp-11-52212011, 2011.

Solazzo, E., Bianconi, R., Vautard, R.,Wyat Appel, K., Moran, M. D., Hogrefe, C., Bessagnet, B., Brandt, J., Christensen, J. H., Chemel, C., Coll, I., Denier van der Gon, H. A. C., Ferreira, J., Forkel, R., Francis, X. V., Grell, 5 G., Grossi, P., Hansen, A. B., Jericevic, A., Kraljevic, L., Miranda, A. I., Nopmongcol, U., Pirovano, G., Prank, M., Riccio, A., Sartelet, K. N., Schaap, M., Silver, J. D., Sokhi, R. S., Vira, J., Werhahn, J., Wolke, R., Yarwood, G., Zhang, J., Rao, S. T., and Galmarini, S.: Model evalution and ensemble modelling of surface-level ozone in Europe and North America in the context of AQMEII, Atmos. Environ., 53, 60-74, 2012a.

Solazzo, E., Bianconi, Pirovano, G., Matthias, V., Vautard, R., Moran, M. D., Wyat Appel, K., Bessagnet, B., Brandt, J., Christensen, J. H., Chemel, C., Coll, I., Ferreira, J., Forkel, R., Francis, X. V., Grell, G., Grossi, P., Hansen, A. B., Miranda, A. I., Nopmongcol, U., Prank, M., Sartelet, K. N., Schaap, M., Silver, J. D., Sokhi, R. S., Vira, J., Werhahn, J., Wolke, R., Yarwood, G., Zhang, J., Rao, S. T., and Galmarini, S.: Operation model evaluation for particulate matter in Europe and North America in the context of AQMEII, Atmos. Environ., 53, 75-92, 2012b.
Steinbacher, M., Zellweger, C., Schwarzenbach, B., Bugmann, S., Buchmann, B., Ordónez, C., Prévot, A. S. H., and Hueglin, C.: Nitrogen oxide measurements at rural sites in Switzerland: bias of conventional measurement techniques, J. Geophys. Res., 112, D11307, doi:10.1029/2006JD007971, 2007.

Stern, R., Builtjes, P. J. H., Schaap, M., Timmermans, R., Vautard, R., Hodzic, A., Memmesheimer, M., Feldmann, H., Renner, E., Wolke, R., and Kerschabumer, A.: A model inter-comparison study focusing on episodes with elevated $\mathrm{PM}_{10}$ concentrations, Atmos. Environ., 42, 4567-4588, 2008.

Tao, Z., Larson, S. M., Williams, A., Caughey, M., and Wuebbles, D. J.: Sensitivity of regional ozone concentrations to temporal distribution of emissions, Atmos. Environ., 38, 6279-6285, 2004.

Thunis, P., Cuvelier, C., Roberts, P., White, L., Post, L:, Tarrason, L., Tsyro, S., Stern, R., Kerschbaumer, A., Rouil, L., Bessagnet, B., Builtjes, P.J.H., Schaap, M., Boersen, G., and Bergstroem, R.: Evaluation of Sectoral Approach to Integrated Assessment Modelling including the Mediterranean Sea. Eurodelta II report 2008, EUR 23444 EN, doi:10.2788/87066, http://publications. jrc.ec.europa.eu/repository/handle/111111111/7504 (last access: January 2014), 2008.

van Loon, M., Roemer, M. G. M., and Builtjes, P. J. H.: Model inter-comparison in the framework of the review of the unified EMEP model, TNO-Report R2004/282, Apeldoorn, the Netherlands, 2004.

van Loon, M., Vautard, R., Schaap, M., Bergström, R., Bessagnet, B., Brandt, J., Builtjes, P. J. H., Christensen, J. H., Cuvelier, K., Graf, A., Jonson, J. E., Krol, M., Langner, J., Roberts, P., Rouil, L., Stern, R., Tarrasón, L., Thunis, P., Vignati, E., White, L., and Wind, P.: Evaluation of long-term ozone simulations from seven regional air quality models and their ensemble average, Atmos. Environ., 41, 2083-2097, 2007.

Villena, G., Bejan, I., Kurtenbach, R., Wiesen, P., and Kleffmann, J.: Interferences of commercial $\mathrm{NO}_{2}$ instruments in the urban atmosphere and in a smog chamber, Atmos. Meas. Tech., 5, 149-159, doi:10.5194/amt-5-149-2012, 2012.

Walcek, C. J. and Aleksic, N. M.: A simple but accurate mass conservative peak-preserving, mixing ratio bounded advection algorithm with fortran code, Atmos. Environ., 32, 3863-3880, 1998.

Wang, X., Liang, X.-Z., Jiang, W., Tao, Z., Wang, J. X. L., Liu, H., Han, Z., Liu, S., Zhang, Y., Grell, G. A., and Peckham, S. E.: WRF-Chem simulation of East Asian air quality: sensitivity to temporal and vertical emissions distributions, Atmos. Environ., 44, 660-669, 2010.

Whitten, G., Hogo, H., and Killus, J.: The Carbon Bond Mechanism for photochemical smog, Environ. Sci. Technol., 14, 690-700, 1980.

Wichink Kruit, R. J., Schaap, M., Sauter, F. J., van Zanten, M. C., and van Pul, W. A. J.: Modeling the distribution of ammonia across Europe including bi-directional surface-atmosphere exchange, Biogeosciences, 9, 5261-5277, doi:10.5194/bg-9-52612012, 2012.

Zhang, L., Gong, S., Padro, J., and Barrie, L.: Size-segregated particle dry deposition scheme for an atmospheric aerosol module, Atmos. Environ., 35, 549-560, 2001. 